\title{
Discusión del artículo "Colgajo lateral de brazo en la reconstrucción de la cavidad oral"
}

\author{
Discussion of the article "Lateral arm flap in the reconstruction of the oral cavity"
}

Los autores presentan una muy bien documentada serie prospectiva de pacientes reconstruidos con el colgajo lateral de brazo, con unos resultado excelentes, al menos en lo referente a la morbilidad de la zona donante y a la supervivencia del colgajo. Se trata de un colgajo poco utilizado en la práctica clínica habitual, razón por la que resulta muy pertinente incluir la descripción de la técnica quirúrgica en el artículo. Las razones de su escaso uso son fundamentalmente la mayor dificultad técnica y sobre todo la menor longitud del pedículo en relación con el colgajo antebraquial. Estos inconvenientes suelen superar al hecho de que la morbilidad del colgajo lateral del brazo es indiscutiblemente mucho menor, por lo que no parece que en el futuro este colgajo llegue a estar a la altura del colgajo antebraquial.

Hay dos aspectos del artículo que merecen una discusión específica, que son el problema de la longitud del pedículo y la cuestión de los colgajos alternativos al colgajo aquí presentado.

En relación con la longitud del pedículo, la opinión de este revisor es que es preferible el uso del sistema venoso superficial, ya que el pedículo es potencialmente mucho más largo, y no se corre el riesgo de comprometer la limpieza de la disección cervical cuando el cirujano se ve tentado a seguir las ramas del tronco tirolinguofacial para que no le sea necesario el uso de un injerto venoso. En la experiencia de este revisor es preferible y oncológicamente más seguro ligar todas las ramas de la vena yugular interna a su salida, y recurrir a una anastomosis venosa terminolateral a la vena yugular interna. Pero para ello es necesario tener la seguridad de que la longitud de pedículo no va a suponer una traba más en la reconstrucción.

En cuanto a los colgajos alternativos, llama la atención que sólo se hayan referido al colgajo antebraquial. Aunque desde su descripción ha sido considerado uno de las opciones fundamentales en la reconstrucción de partes blandas de cabeza y cuello (y por lo tanto "el rey a destronar"), cada vez más los colgajos de perforantes como el anterolateral de muslo (ALT en su acrónimo inglés) y el de arteria epigástrica inferior profunda (DIEAP en su acrónimo anglosajón) están realmente sustituyendo al colgajo antebraquial, cuya morbilidad de la zona donante puede llegar a ser muy importante.

El colgajo ALT se basa en los vasos perforantes septocutáneos o musculocutáneos de la rama descendente de la arteria circunfleja femoral lateral. ${ }^{1}$ La longitud del pedículo suele ser de unos $15 \mathrm{~cm}$. Es un colgajo muy versátil. Puede obtenerse un colgajo de $8 \mathrm{~cm}$ de anchura y de la práctica totalidad de la longitud del muslo y conseguir un cierre directo de la zona donante. Aunque lo más frecuente es utilizar un colgajo fasciocutáneo, puede prescindirse de la fascia o de la piel; o puede incluirse un fragmento de músculo vasto lateral.
The authors present a well documented prospective series of patients reconstructed using a lateral arm flap with excellent results in terms of donor zone morbidity and flap survival. This flap is currently little used in routine clinical practice, which is why it is pertinent to include the description of the surgical technique in the article. The reasons why it is little used are mainly its greater technical difficulty, particularly the shorter pedicle length compared to the forearm flap. These drawbacks usually outweigh the fact that the lateral arm flap unquestionably has much less morbidity, which is why it is likely that this flap will never be as widely used as the forearm flap.

Two aspects of the article deserve specific discussion, i.e., the problem of pedicle length and the question of alternative flaps to the flap discussed here.

With regard to pedicle length, the opinion of this reviewer is that it is preferable to use the superficial venous system because the pedicle is potentially much longer and there is no risk of jeopardizing the cleanliness of the cervical dissection when the surgeon is tempted to follow the branches of the thyrolinguofacial trunk to avoid using a venous graft. In the experience of this reviewer, it is better and oncologically safer to ligate all the branches of the internal jugular vein at its outflow point and perform end-to-side venous anastomosis to the internal jugular vein. To do this, it is necessary to ensure that pedicle length will not be a problem for reconstruction.

As for alternative flaps, it is noteworthy that the authors only mention the forearm flap. Although it is clear from their description that it was one of the main options considered in the soft-tissue reconstruction of the head and neck (and, therefore, "the king to be overthrown"), anterolateral thigh perforating flaps (ALT) and deep inferior epigastric artery flaps DIEAP) are, in fact, replacing with increasing frequency forearm flaps, which can produce major morbidity in the donor zone.

The ALT flap is based on the septocutaneous or musculocutaneous perforating vessels of the descending branch of the lateral femoral circumflex artery. ${ }^{1}$ The pedicle length is usually about $15 \mathrm{~cm}$. It is a very versatile flap. A flap about $8 \mathrm{~cm}$ wide and almost as long as the thigh can be obtained and used for direct closure of the donor zone. Although a fasciocutaneous flap is used most frequently, the fascia or skin can be dispensed with, or a fragment of vastus lateralis 
La isla cutánea también puede dividirse en tantas raquetas cutáneas independientes como vasos perforantes sean disecados.

La ventaja fundamental del colgajo ALT es la gran reducción de la morbilidad de la zona donante. Desde que se empezó a usar en su Servicio, en los últimos 2 años este revisor ha efectuado trece colgajos ALTs y tan sólo tres colgajos antebraquiales (en dos de los casos por fracaso de la isla cutánea de un colgajo peroneal, situaciones en las que era recomendable reducir al máximo el tiempo quirúrgico).

Merece mención aparte recalcar que el grosor de la reconstrucción influye decisivamente en el resultado estético y funcional. El colgajo ALT ofrece una gran versatilidad en grosor y además la cantidad de tejido que puede obtenerse del muslo resulta más que suficiente para las necesidades reconstructivas de cabeza y cueIlo. En los pacientes con un grueso panículo adiposo es posible desgrasar considerablemente el colgajo; en los pacientes delgados suele ser posible doblar sobre sí mismo el colgajo si es necesario para aumentar el grosor de la reconstrucción (o utilizar un colgajo DIEAP, más grueso). Tanto el colgajo lateral del brazo como el colgajo antebraquial podrían ser especialmente útiles en reconstrucción faríngea por su escaso grosor. Sin embargo, en la cavidad oral puede ser más adecuado un colgajo algo más grueso.

La reconstrucción de los defectos tras hemiglosectomía es controvertida; 3 de los 10 pacientes de la serie de los autores se presentan con tales defectos. Aunque en ocasiones puede ser aceptable el cierre directo, en muchas ocasiones se prefiere reconstruir. La tendencia habitual es el uso de un injerto lo más fino posible, para permitir una función irrestricta del remanente lingual. Sin embargo, en nuestro servicio, en el que prácticamente se ha sustituido el colgajo antebraquial por el colgajo anterolateral de muslo, venimos observando que la función de la lengua remanente parece más adecuada si se reconstruye todo el volumen extirpado, aunque sea con un tejido inerte como el tejido adiposo. El colgajo antebraquial es demasiado fino para ese propósito, y sin embargo el colgajo anterolateral de muslo suele adaptarse de un modo sorprendentemente fiel.

El caso que ilustra esta discusión es el de una mujer de 25 años sin antecedentes de interés ni hábitos tóxicos, diagnosticada de un carcinoma epidermoide de cara lateral de lengua. Se efectuó una hemiglosectomía izquierda, disección funcional bilateral y reconstrucción con un colgajo ALT del muslo derecho. A los 8 meses la paciente podía llevar una dieta sin restricciones y el habla era prácticamente normal.

\section{Bibliografía}

1. J.S. Chana, F.C. Wei. A review of the advantages of the anterolateral thigh flap in head and neck reconstruction. Br J Plast Surg 2004;57:603-609.

J. Arias Gallo

Médico Adjunto. Servicio de Cirugía Oral y Maxilofacial. Hospital Universitario La Paz. Madrid, España

Lorena Pingarrón Martín Médico Residente. Servicio de Cirugía Oral y Maxilofacial. Hospital Universitario La Paz. Madrid, España muscle can be included. The cutaneous island also can be divided into as many independent tennis racket-shaped cutaneous flaps as the number of perforating vessels dissected.

The main advantage of the ALT flap is that it greatly reduces donor zone morbidity. Since the ALT flap first began to be used in our department, in the last 2 years this reviewer has prepared thirteen ALT flaps and only three forearm flaps (in two cases for failure of the cutaneous island of a peroneal flap, situations in which surgical time should be shortened as much as possible).

It should be stressed that the thickness of the reconstruction decisively influences the aesthetic and functional result. The ALT flap is highly versatile in thickness and the amount of tissue that can be obtained from the thigh is more than sufficient for the reconstructive needs of the head and neck. In patients with a thick fat layer, the flap can be defatted considerably; in thin patients it can usually be folded to increase the thickness of the reconstruction (or a DIEAP flap, which is thicker, can be used). Both the lateral arm flap and the forearm flap can be especially useful in pharyngeal reconstruction due to their reduced thickness. However, a thicker flap may be more suitable in the oral cavity.

Reconstruction of the defects after hemiglossectomy is controversial. Three of the 10 patients in the authors' series present such defects. Although direct closure sometimes may be acceptable, on many occasions reconstruction is preferred. The usual tendency is to use the thinnest possible graft to allow unrestricted function of the lingual remnant. Nevertheless, in our department, in which the forearm flap has practically been replaced by the anterolateral thigh flap, we have observed that the function of the remnant tongue seems to be more suitable if the entire volume excised is reconstructed, even if done with an inert tissue like fatty tissue. The forearm flap is too thin for that purpose but, however, the anterolateral thigh flap usually adapts in a surprising faithful way.

The case that illustrates this discussion is that of a 25 year-old woman without a history of interest or toxic habits, who was diagnosed of squamous-cell carcinoma of the lateral tongue. Left hemiglossectomy, functional bilateral dissection, and reconstruction with an ALT flap of the right thigh was performed. At 8 months the patient could eat and unrestricted diet and her speech was almost normal. 